\title{
Combined effect of polymorphisms in Rad51 and $X R C C 3$ on breast cancer risk and chromosomal radiosensitivity
}

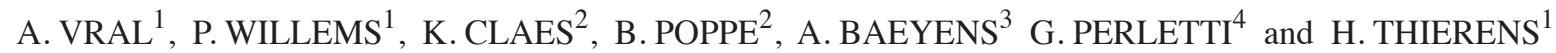 \\ ${ }^{1}$ Department of Basic Medical Sciences, Ghent University, De Pintelaan 185 (6B3); ${ }^{2}$ Centre for Medical Genetics, \\ Ghent University Hospital, De Pintelaan 185, B-9000 Ghent, Belgium; ${ }^{3}$ Department of Radiation Biophysics , \\ iThemba LABS, Somerset West, Republic of South Africa; ${ }^{4}$ Laboratory of Toxicology and Pharmacology, Department \\ of Biomedical, Inf./Comm. Sciences, Università degli Studi dell'Insubria, 21052 Busto A/Varese, Italy
}

Received February 24, 2011; Accepted June 2, 2011

DOI: $10.3892 / \mathrm{mmr} .2011 .523$

\begin{abstract}
Enhanced in vitro chromosomal radiosensitivity (CRS) has been proposed as a marker for low-penetrance gene mutations predisposing to breast cancer (BC). Since the double strand break (DSB) is the most detrimental form of DNA damage induced by ionizing radiation, it is possible that mutations in genes encoding proteins involved in DSB repair affect breast cancer risk. The purpose of the present study was to examine whether five single nucleotide polymorphisms (SNPs) in Rad51 and Xrcc3 (rs1801320, rs1801321, rs1799796, rs861539 and rs1799794) exhibited an association with breast cancer susceptibility in a Belgian population of $\mathrm{BC}$ patients with a known or putative genetic predisposition. We also ascertained whether a relationship exists between the occurrence of the 'variant' alleles of these variations and in vitro CRS. Blood samples were obtained from BC patients and from healthy female individuals. Variations in the 5' UTR of Rad51 and $X r c c 3$ were genotyped, and statistical analysis was performed. The results showed that low-penetrant variations in Rad51 and Xrcc3, two proteins belonging to the homologous recombination DSB repair pathway, may modify BC risk in patients already carrying a pathological mutation in the highly penetrant $\mathrm{BC}$ genes $B R C A 1$ and $B R C A 2$. Combined risk genotype analysis revealed that Rad51 SNPs enhance BC risk in $B R C A 2$ patients, whereas $X r c c 3$ SNPs significantly enhance $\mathrm{BC}$ risk in carriers of $B R C A 1$ mutations and in patients with hereditary BC. When four putative risk genotypes of Rad5I and $X r c c 3$ were combined, positive significant odds ratios were obtained in the entire patient population and in patients with a hereditary history of disease. Although obtained from a limited number of patients, our data are supportive of a polygenic model whereby combinations of weak variations
\end{abstract}

Correspondence to: Dr Gianpaolo Perletti, Laboratory of Toxicology and Pharmacology, Department of Biomedical, Inf./ Comm. Sciences, Università degli Studi dell'Insubria, Via A. Da Giussano, 12, 21052 Busto A, Italy

E-mail: gianpaolo.perletti@uninsubria.it

Key words: genetic polymorphisms, breast cancer, XRCC3, Rad51, radiosensitivity, DNA repair are responsible for an enhanced $\mathrm{BC}$ risk by acting jointly with high-penetrant mutations in BRCA1 or BRCA2.

\section{Introduction}

Breast cancer (BC) is the most frequently occurring cancer in women worldwide, with an estimated 1.15 million new cases in 2002 (23\% of all cancers). More than half of the cases occurred in the industrialized countries of Europe and North America (1). In Europe, BC accounted for $28.9 \%$ of all cancer cases in women in 2006 and was the leading cause of cancer death in the European Union (16.7\%) (2).

In a number of independent studies, enhanced in vitro chromosomal radiosensitivity (CRS) has been demonstrated in a significant number of breast cancer patients (3-8). In vitro $\mathrm{CRS}$ is therefore considered to be a hallmark for $\mathrm{BC}$ and a marker for low-penetrant gene mutations predisposing to $\mathrm{BC}$ $(3,4,6,7,9)$. The most detrimental form of ionizing radiationinduced DNA damage is the double strand break (DSB) due to its ability to generate chromosomal aberrations when misrepaired or left unrepaired. The fact that DSB-initiated chromosomal instability may eventually trigger carcinogenesis in the breast epithelium is supported by evidence that breast cancer susceptibility genes such as BRCA1 and BRCA2, and ATM and TP53 play crucial roles in DNA DSB repair and chromosome stability $(10,11)$.

DSB repair in mammalian cells involves the error-free homologous recombination (HR) and the error-prone nonhomologous end joining (NHEJ) pathways (reviewed in ref. 12). The cell cycle determines which pathway is activated after double strand breakage in a eukaryotic cell. The more accurate HR response mechanism is activated in the $S / G_{2}$ phase, when the sister chromatid provides a correct template of the damaged sequence for alignment. On the other hand, while the more error-prone mechanism of NHEJ is the favoured pathway in cells in the $G_{0} / G_{1}$ phase. The inactivity of either pathway was shown to lead to potentially oncogenic translocations and other karyotypic changes in animal models (13). In humans, inherited genetic defects in these pathways often manifest as an increased CRS (14). For example, downregulation or mutation of DNA DSB repair proteins involved in the NHEJ pathway were shown to be associated with both BC risk and enhanced CRS (15-18). 
The main event of HR is the homology search and DNA strand invasion by the Rad51-ssDNA presynaptic filament, positioning the invading 3 '-end on a template duplex DNA to initiate repair synthesis. Additionally, cofactors that promote assembly or stabilization of the Rad51 ssDNA filament as well as the disassembly of the Rad51-DNA complexes are significant. These cofactors include five Rad51 paralogs (Rad51B, Rad51C, Rad51D, Xrcc2 and Xrcc3) that are required for the in vivo Rad51 filament formation $(19,20)$. In addition, the Xrcc3/Rad51C heterodimer appears to be required for the resolution of Holliday Junctions generated during HR (21). In this process, BRCA2 supports Rad51 filament formation, nucleation and filament stabilisation and is required for the ionizing radiation-induced formation of Rad51 foci in vivo. In addition, the formation of radiation damage-induced Rad51 foci requires functional Xrcc3 (22) and BRCA1 (10).

The relationship between mutations in BRCA1/BRCA2 and $\mathrm{BC}$ risk is well known. Since HR is a key pathway in the maintainance of genomic stability, mutations in additional genes encoding proteins involved in HR are likely to affect cancer risk. To prove this hypothesis, different polymorphisms in $\operatorname{Rad} 51$ (23-33) and Xrcc3 (22,25,26,33-43) were previously investigated, with conflicting results. In this study, we examined whether two single nucleotide polymorphisms (SNPs) in the 5' untranslated region (UTR) of the Rad51 gene and three SNPs in Xrcc3 exhibited an association with breast cancer susceptibility in a Belgian population of BC patients with a known or putative genetic predisposition. We also investigated whether a relationship existed between the occurrence of the variant alleles of these variations and in vitro $\mathrm{CRS}$.

\section{Materials and methods}

Study population. The control population for this study included 172 healthy women (mainly staff members of Ghent University and Ghent University Hospital). Blood samples were obtained during the annual occupational medical examination. This control group did not include aged individuals. Thus, for age-matching purposes, blood samples from elderly healthy women were obtained during local senior club meetings. Written informed consent was provided by all members of the control group.

Samples of breast cancer patients were obtained in co-operation with the Centre for Medical Genetics of the Ghent University Hospital. The patients met at least one of the following criteria: i) patients were required to have at least 3 first-degree relatives with breast and/or ovarian cancer; or ii) belong to families, including at least two first- and/or seconddegree relatives diagnosed with breast and/or ovarian cancer before the average age of 50; or iii) be affected by bilateral breast cancer with both tumors diagnosed before the age of 50 ; or iv) were required to have been diagnosed with $\mathrm{BC}$ prior to the age of 40 , but not have a family history of the disease. Since a positive family history and/or diagnosis at a young age are regarded as significant risk factors for the development of hereditary breast cancer, the patients were screened for mutations in the BRCA1 and BRCA2 genes at the Centre for Medical Genetics, as previously described (44).

Patients were provided with genetic counselling and signed informed consent was provided by all of the patients.
The present study was approved by the Review Board of the first author's institution.

For statistical analysis, the breast cancer population was divided into groups of patients showing: i) hereditary $\mathrm{BC}$; ii) familial $\mathrm{BC}$ and iii) sporadic cases at young age, but without a family history of BC. In 'hereditary' BC families, an autosomal dominant Mendelian pattern indicated that the disease was inherited, whereas BC was considered to be 'familial' when the frequency of the disease was clearly higher within the family when compared to the general population, but the criteria for hereditary $\mathrm{BC}$ were not met.

To evaluate whether the presence of a known mutation in $B R C A 1$ and/or BRCA2 affected the association between the SNPs under study and BC susceptibility, the patient population was also divided into groups of carriers of $B R C A 1$ and/or BRCA2 mutations.

Depending on the availability of genetic material, different numbers of patients were included for analysis of the different SNPs. The number of controls and patients evaluated for each SNP and the mean age of the population are shown in Table I.

Collection and preparation of blood samples. In vitro CRS was examined in a total of 62 patients. Samples $(20 \mathrm{ml})$ of heparinized blood were obtained from the 62 patients and from matched control female individuals. Within $6 \mathrm{~h}$ after venepuncture, blood cultures (from $5 \mathrm{ml}$ whole blood) were started to assess in vitro CRS using the $\mathrm{G}_{2}$ chromatid break and the $\mathrm{G}_{0}$ micronucleus $(\mathrm{MN})$ assays $(3,4)$. The two cytogenetic assays quantify the extent of DNA damage induced by irradiation during the $G_{0}$ or $G_{2}$ phases of the cell cycle. Lymphocyte separation was performed on part of the blood samples within $24 \mathrm{~h}$ after venepuncture, using lymphoprep (Axis-Shield, Lucron, Dieren, The Netherlands). Isolated lymphocytes were stored in liquid nitrogen until DNA extraction was performed (QIAamp DNA Blood Mini Kit, Qiagen, Hilden, Germany).

Genotyping. The c.-98 G>C (rs1801320) and c.-61 G>T (rs1801321) variations in the 5' UTR of Rad51, and the c.562-14 A>G (rs1799796), c.722 C>T (rs861539) and c.-316 $\mathrm{A}>\mathrm{G}$ (rs1799794) variations in Xrcc3 were genotyped using a polymerase chain reaction (PCR), combined with restriction fragment length polymorphism analysis or a SnapShot technique. The SNPs were named using the current nomenclature of the Human Genome Variation Society (45). The reference sequences of the corresponding genes are shown in Table II.

PCR products of control individuals were amplified using 100-200 ng DNA in a $25 \mu \mathrm{l}$ reaction containing $0.5 \mathrm{mM}$ dNTPs (Amersham Bioscience, Gent, Belgium), 1X PCR buffer (Invitrogen, Merelbeke, Belgium), $1.5 \mathrm{mM} \mathrm{MgCl}_{2}$ (Invitrogen), $1 \mathrm{mM}$ forward and reverse primers (Invitrogen) and 0.6 units Platinum Taq polymerase (Invitrogen). The PCR reaction of patient DNA contained $60 \mathrm{ng}$ DNA in a $16 \mu 1$ reaction, including $0.3 \mathrm{mM}$ dNTPs, $0.6 X$ PCR buffer, $0.9 \mathrm{mM}$ $\mathrm{MgCl}_{2}, 0.9 \mathrm{mM}$ forward and reverse primers and 0.36 units Platinum Taq polymerase. Table I shows the sequences of primers used in this study.

DNA fragments containing Rad51 SNPs were amplified by an initial denaturation step of $94^{\circ} \mathrm{C}$, followed by 12 cycles including steps of denaturation at $94^{\circ} \mathrm{C}$ for $20 \mathrm{sec}$, annealing at $58^{\circ} \mathrm{C}$ and elongation at $72^{\circ} \mathrm{C}$ for $1 \mathrm{~min}$. At each cycle, the 


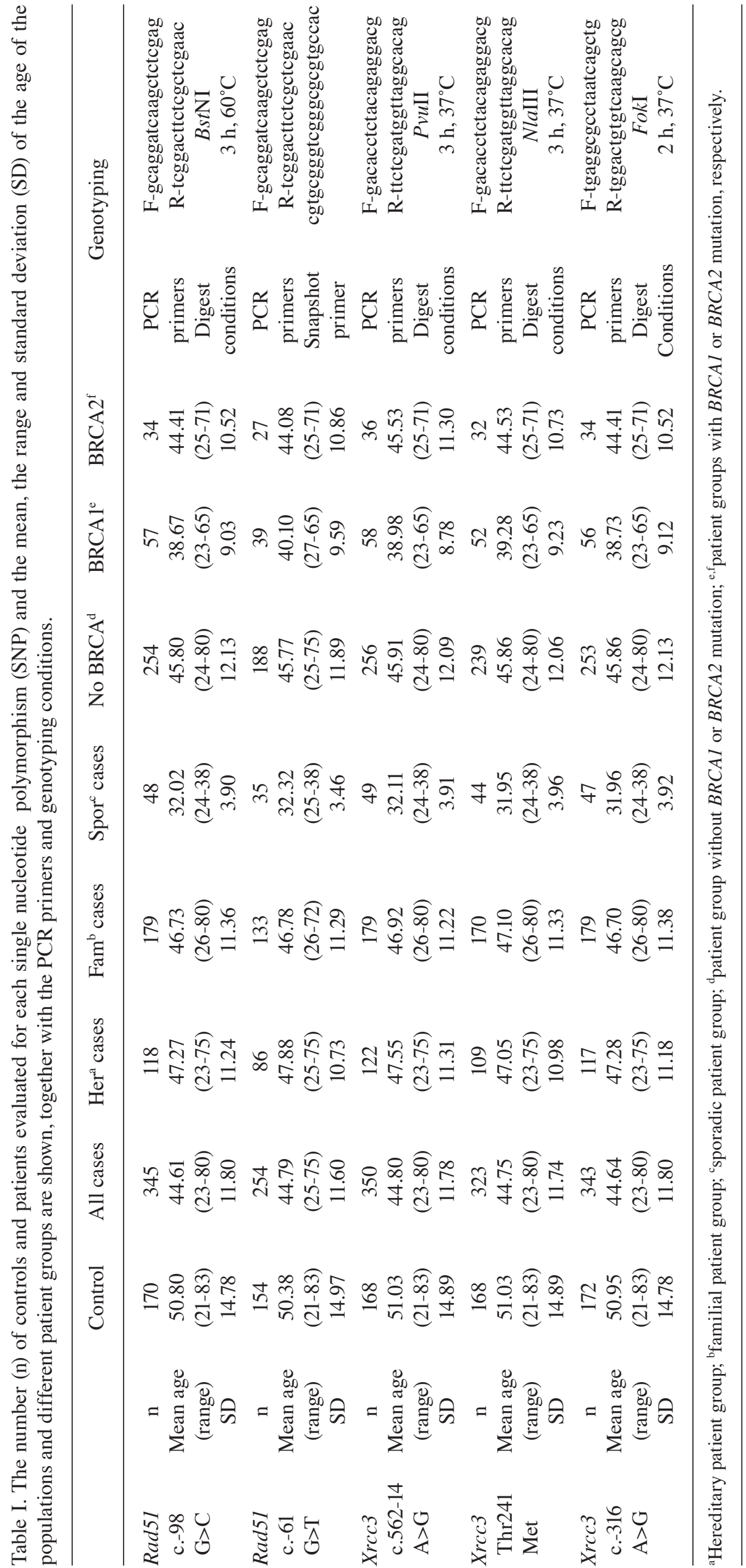


Table II. Chromosomal location of Rad51 and XRCC3, and reference sequences used to name the polymorphisms under investigation. ${ }^{2}$

\begin{tabular}{|c|c|c|c|c|}
\hline $\begin{array}{l}\text { Gene, chromosomal } \\
\text { location and reference } \\
\text { sequence }\end{array}$ & $\begin{array}{l}\text { SNP (alternative name, } \\
\text { rs no. on NCBI) }\end{array}$ & $\begin{array}{l}\text { Variant allele } \\
\text { frequency }\end{array}$ & $\begin{array}{l}\text { Variant allele frequency } \\
\text { (published in NCBI) }\end{array}$ & HWE $(p>0.05)$ \\
\hline \multicolumn{5}{|l|}{$\operatorname{Rad} 51$} \\
\hline $15 q 15.1$ & $\begin{array}{c}\text { c. }-98 \mathrm{G}>\mathrm{C} \\
\left(5^{\prime} \mathrm{UTR} 135 \mathrm{G}>\mathrm{C},\right. \\
\text { rs1801320) }\end{array}$ & $\begin{array}{r}\text { Controls: } 4 \% \\
\text { Cases: } 6 \%\end{array}$ & European pop: $6.7 \%$ & $\begin{array}{r}\text { Controls: } 0.834 \\
\text { Cases: } 0.543\end{array}$ \\
\hline $\begin{array}{l}\text { Ref. sequence: } \\
\text { NM_002875.3 }\end{array}$ & $\begin{array}{c}\text { c. }-61 \mathrm{G}>\mathrm{T} \\
\text { (5' UTR } 172 \mathrm{G}>\mathrm{T}, \\
\text { rs1801321) }\end{array}$ & $\begin{array}{r}\text { Controls: } 41 \% \\
\text { Cases: } 42 \%\end{array}$ & $\begin{array}{l}\text { European pop: } 46.7 \% \\
\text { Caucasian pop: } 43.3 \%\end{array}$ & $\begin{array}{r}\text { Controls: } 0.571 \\
\text { Cases: } 0.582\end{array}$ \\
\hline $\begin{array}{l}\text { XRCC } 3 \\
14 q 32.3\end{array}$ & $\begin{array}{c}\text { c. } 562-14 \mathrm{~A}>\mathrm{G} \\
(\mathrm{IVS} 5-14 \mathrm{~A}>\mathrm{G}, \\
\mathrm{A} 17893 \mathrm{G}, \\
\text { rs1799796) }\end{array}$ & $\begin{array}{r}\text { Controls: } 29 \% \\
\text { Cases: } 31 \%\end{array}$ & $\begin{array}{l}\text { European pop: } 31.7 \% \\
\text { Caucasian pop: } 33.3 \%\end{array}$ & $\begin{array}{r}\text { Controls: } 0.631 \\
\text { Cases: } 0.615\end{array}$ \\
\hline \multirow[t]{2}{*}{$\begin{array}{l}\text { Ref. sequence: } \\
\text { NM_001100119.1 }\end{array}$} & $\begin{array}{l}\text { c. } 722 \mathrm{C}>\mathrm{T} \\
\text { (Thr241Met, } \\
\text { C18067T, } \\
\text { rs861539) }\end{array}$ & $\begin{array}{r}\text { Controls: } 43 \% \\
\text { Cases: } 38 \%\end{array}$ & $\begin{array}{l}\text { European pop: } 41.7 \% \\
\text { Caucasian pop: } 45 \%\end{array}$ & $\begin{array}{r}\text { Controls: } 0.964 \\
\text { Cases: } 0.858\end{array}$ \\
\hline & $\begin{array}{c}\text { c. }-316 A>G \\
\left(5^{\prime} \text { UTR } 4541\right. \\
A>G, r s 1799794)\end{array}$ & $\begin{array}{r}\text { Controls: } 17 \% \\
\text { Cases: } 21 \%\end{array}$ & $\begin{array}{l}\text { European pop: } 18.4 \% \\
\text { Caucasian pop: } 15.5 \%\end{array}$ & $\begin{array}{l}\text { Controls: } 0.590 \\
\text { Cases: } 0.743\end{array}$ \\
\hline
\end{tabular}

${ }^{a}$ The five single nucleotide polymorphisms with variant allele frequencies in the control and patient populations are compared to the variant allele frequencies shown in NCBI (http://www.ncbi.nlm.nih.gov/). The genotype distributions were compared to those expected from the Hardy-Weinberg equilibrium (HWE) using a $\chi^{2}$ test.

annealing temperature was decreased by $1^{\circ} \mathrm{C}$. This was followed by 24 cycles at $94^{\circ} \mathrm{C}(40 \mathrm{sec})$, at $46^{\circ} \mathrm{C}(40 \mathrm{sec})$ and at $72^{\circ} \mathrm{C}(30 \mathrm{sec})$, and by a final extension step at $72^{\circ} \mathrm{C}(10 \mathrm{~min})$. The DNA fragments containing c.562-14 $\mathrm{A}>\mathrm{G}$ and c.722C $>\mathrm{T}$ in $X r c c 3$ and the fragment surrounding the $X r c c 3$ c.-316 $\mathrm{A}>\mathrm{G}$ SNP were amplified using a 35 -cycle $\mathrm{PCR}$ program consisting of an initial denaturation step at $95^{\circ} \mathrm{C}$ for $5 \mathrm{~min}$, followed by 35 cycles of $3 \mathrm{~min}$, including a denaturation step at $95^{\circ} \mathrm{C}$ (1 min), an annealing step at $58^{\circ} \mathrm{C}(1 \mathrm{~min})$ and an elongation step at $72^{\circ} \mathrm{C}(1 \mathrm{~min})$, followed by a final extension step of $10 \mathrm{~min}$ at $72^{\circ} \mathrm{C}$. The efficiency of the PCR reaction was confirmed by electrophoresis on a $1.5 \%$ agarose gel. A negative control containing water was included during each PCR reaction to exclude contamination.

To genotype the 5' UTR c.-61 G>T SNP, the SnapShot multiplex system was utilized (Applied Biosystems, Halle, Belgium). SnapShot primers are shown in Table I. Analysis of $2 \mu \mathrm{l}$ of the SnapShot products [with $10 \mu \mathrm{l}$ Amresco Capillary Electrophoresis buffer (Lucron Bioproducts, Dieren, The Netherlands) and 0.3 $\mu$ LIZ-120 Size Standard (Applied Biosystems)] was performed on the capillary system of the ABI Prism 3730 Genetic Analyser (Applied Biosystems). Results were visualised on an Applied Biosystems Peak scanner, version 1.0. To genotype the c.-98 G>C SNP in Rad51 and the three SNPs in Xrcc3, PCR products were digested with sequence-specific restriction endonucleases (Table I). Digested products were then analysed by electrophoresis on a $2 \%$ agarose gel and visualised under ultraviolet light after ethidium bromide staining.

Statistical analysis. Statistical analysis of the data was performed using Microsoft office Excel 2007 or the Statistical Package for Social Sciences (SPSS), version 15.0.

The association of the five SNPs with BC risk was evaluated by calculating age-corrected odds ratios (ORs) by means of logistic regression. To improve the statistical power of the analytical investigation, particularly for the rare homozygous variant (HV) genotypes, the OR was calculated for the heterozygous (He) or HV genotypes using the homozygous normal (HN) genotype as reference, and for the He and HV genotypes combined in a single group. The complete control population was always used to compare genotype frequencies with those found in the different patient groups (divided by family history or presence of a BRCA1/BRCA2 mutation).

The observed genotype distributions were compared with those expected from the Hardy-Weinberg equilibrium (HWE) using a standard $\chi^{2}$ test. The linkage disequilibrium (LD) coefficient $r^{2}$ between the analyzed SNPs was calculated using Haploview (version 4.0) (46).

\section{Results}

Comparison of variant allele and standard frequencies. The observed genotype distributions of the five analyzed SNPs 
Table III. Genotype frequencies in control subjects and in the total patient population (all cases).

\begin{tabular}{|c|c|c|c|c|c|c|}
\hline & & \multirow{2}{*}{$\begin{array}{l}\text { Controls } \\
\% \text { (No.) }\end{array}$} & \multicolumn{4}{|c|}{ All Cases } \\
\hline & & & $\%$ (No.) & Corr OR & $(95 \% \mathrm{CI})$ & $\mathrm{p}(\alpha=0.05)$ \\
\hline \multirow{4}{*}{$\begin{array}{r}\text { Rad51 } \\
\text { c.-98 } \\
\mathrm{G}>\mathrm{C}\end{array}$} & GG & 91.18 (155) & $87.54(302)$ & Ref. & & \\
\hline & GC & $8.82(15)$ & $12.46(43)$ & 1.42 & $(0.76-2.67)$ & 0.275 \\
\hline & $\mathrm{CC}$ & $0.00(0)$ & $0.00(0)$ & & & \\
\hline & $\mathrm{GC}+\mathrm{CC}$ & $8.82(15)$ & $12.46(43)$ & 1.42 & $(0.76-2.67)$ & 0.275 \\
\hline \multirow{4}{*}{$\begin{array}{c}\operatorname{Rad} 51 \\
\text { c. }-61 \\
\mathrm{G}>\mathrm{T}\end{array}$} & GG & $32.47(50)$ & $33.86(86)$ & Ref. & & \\
\hline & GT & $52.60(81)$ & $45.28(115)$ & 0.93 & $(0.58-1.47)$ & 0.742 \\
\hline & $\mathrm{TT}$ & $14.94(23)$ & $20.87(53)$ & 1.40 & $(0.76-2.59)$ & 0.287 \\
\hline & GT+TT & $67.53(104)$ & $66.14(168)$ & 1.03 & $(0.67-1.60)$ & 0.882 \\
\hline \multirow{5}{*}{$\begin{array}{l}X R C C 3 \\
\text { c.562-14 } \\
\mathrm{A}>\mathrm{G}\end{array}$} & $\mathrm{AA}$ & $48.21(81)$ & 48.29 (169) & Ref. & & \\
\hline & $\mathrm{AG}$ & $44.64(75)$ & $43.14(151)$ & 0.93 & $(0.63-1.38)$ & 0.714 \\
\hline & GG & $7.14(12)$ & $8.57(30)$ & 1.22 & $(0.58-2.55)$ & 0.600 \\
\hline & $\mathrm{AG}+\mathrm{GG}$ & $51.79(87)$ & $51.71(181)$ & 0.97 & $(0.66-1.42)$ & 0.869 \\
\hline & $\mathrm{CC}$ & $32.14(54)$ & 36.84 (119) & Ref. & & \\
\hline \multirow{3}{*}{$\begin{array}{l}\text { XRCC3 } \\
\text { Thr241Met }\end{array}$} & $\mathrm{CT}$ & $50.00(84)$ & 49.23 (159) & 0.86 & $(0.56-1.31)$ & 0.479 \\
\hline & $\mathrm{TT}$ & $17.86(30)$ & $13.93(45)$ & 0.78 & $(0.44-1.41)$ & 0.414 \\
\hline & $\mathrm{CT}+\mathrm{TT}$ & $67.86(114)$ & $63.16(204)$ & 0.84 & $(0.56-1.26)$ & 0.396 \\
\hline \multirow{4}{*}{$\begin{array}{c}X R C C 3 \\
\mathrm{c} .-316 \\
\mathrm{~A}>\mathrm{G}\end{array}$} & $\mathrm{AA}$ & $68.02(117)$ & $64.14(220)$ & Ref. & & \\
\hline & $\mathrm{AG}$ & $30.23(52)$ & 31.49 (108) & 1.03 & $(0.68-1.56)$ & 0.892 \\
\hline & GG & $1.74(3)$ & $4.37(15)$ & 2.47 & $(0.68-8.94)$ & 0.168 \\
\hline & $\mathrm{AG}+\mathrm{GG}$ & $31.98(55)$ & $35.86(123)$ & 1.11 & $(0.74-1.65)$ & 0.619 \\
\hline
\end{tabular}

Risk genotype analyses.

\begin{tabular}{lcccccc}
\hline & \multirow{2}{*}{$\begin{array}{c}\text { Risk genotypes } \\
\text { (No.) }\end{array}$} & Controls & \multicolumn{4}{c}{ All cases } \\
\cline { 5 - 7 } & $\%($ No. $)$ & $\%($ No. $)$ & Corr OR & $(95 \%$ CI $)$ & $\mathrm{p}(\alpha=0.05)$ \\
\hline Rad51 $^{\text {a }}$ & 0 & $75.32(116)$ & $68.11(173)$ & Ref. & & \\
& $>1$ & $24.68(38)$ & $31.11(89)$ & 1.39 & $(0.87-2.20)$ & 0.387 \\
XRCC3 $^{\text {b }}$ & 0 & $91.67(154)$ & $86.18(293)$ & Ref. & & \\
& $>1$ & $8.33(14)$ & $13.82(47)$ & $\mathbf{1 . 7 9}$ & $\mathbf{( 0 . 9 4 - 3 . 4 1 )}$ & $\mathbf{0 . 0 7 6}$ \\
Rad51 and $_{X R C C 3^{c}}$ & 0 & $70.67(106)$ & $60.32(152)$ & Ref. & & \\
& $>1$ & $29.33(44)$ & $39.68(100)$ & $\mathbf{1 . 5 9}$ & $\mathbf{( 1 . 0 2 - 2 . 4 7 )}$ & $\mathbf{0 . 0 4 1}$ \\
\hline
\end{tabular}

${ }^{\mathrm{a}} \mathrm{c} .-98 \mathrm{G}>\mathrm{T}$ and c.-61 G>T; ${ }^{\mathrm{c} c .562-14}$ and c.-316 A>G; ${ }^{\mathrm{c}} \mathrm{c} .-98 \mathrm{G}>\mathrm{T}$ and c.-61 G>T (Rad51), and c.562-14 and c.-316 A>G (Xrcc3). Age-corrected ORs (Corr OR) for each individual single nucleotide polymorphism (SNP) and for grouped 'risk genotypes' are shown, together with 95\% confidence intervals (95\% CI). Significant and borderline-significant findings are highlighted.

showed no systematic deviation from the HWE $(\mathrm{p}>0.05)$. Comparison of the variant allele frequency of our control population with standard frequencies published on NCBI (47) resulted in no significant deviations (Table II).

Variations in Rad51 and Xrcc3 and breast cancer risk. Age-corrected ORs indicative of an association between individual SNPs in Rad51 or Xrcc3 and BC risk in the total patient population are recorded in Table III. Table IV shows the ORs for patient groups classified on the basis of familial history, whereas in Table $\mathrm{V}$ patient groups are subdivided depending on the presence or absence of a mutation in BRCAI or $B R C A 2$. No significant associations were found between individual SNPs and breast cancer risk. On the other hand, the c.-316 A>G SNP in Xrcc3 exhibited high, borderline-significant ORs in BRCAl mutation carriers $(\mathrm{ORHe}+\mathrm{HV}=1.92$, $\mathrm{p}=0.053$, Table V). The ORs calculated for the c.722 C>T (Thr241Met) variation in $X r c c 3$ were found to be $\leq 1$ in most cases (Tables III-V), indicating that the variant ' $\mathrm{T}$ ' allele is not a risk allele for BC. Concerning the c.-98 G>C SNP in Rad51, a non-significant enhancement of $\mathrm{BC}$ risk was observed for the heterozygous genotype $(\mathrm{OR}>1)$ in the total patient population (Table III) as well as in patient groups divided on the basis of familial history or BRCA mutations (Tables IV and $\mathrm{V}$ ), with the exception of sporadic cases diagnosed at a young age (Table IV). As regards the c.-61 G>T variation in Rad51, and the c.562-14 A>G and c.-316 A>G SNPs in Xrcc3, the 'homozygous variant' genotypes mostly yielded ORs $>1$. 


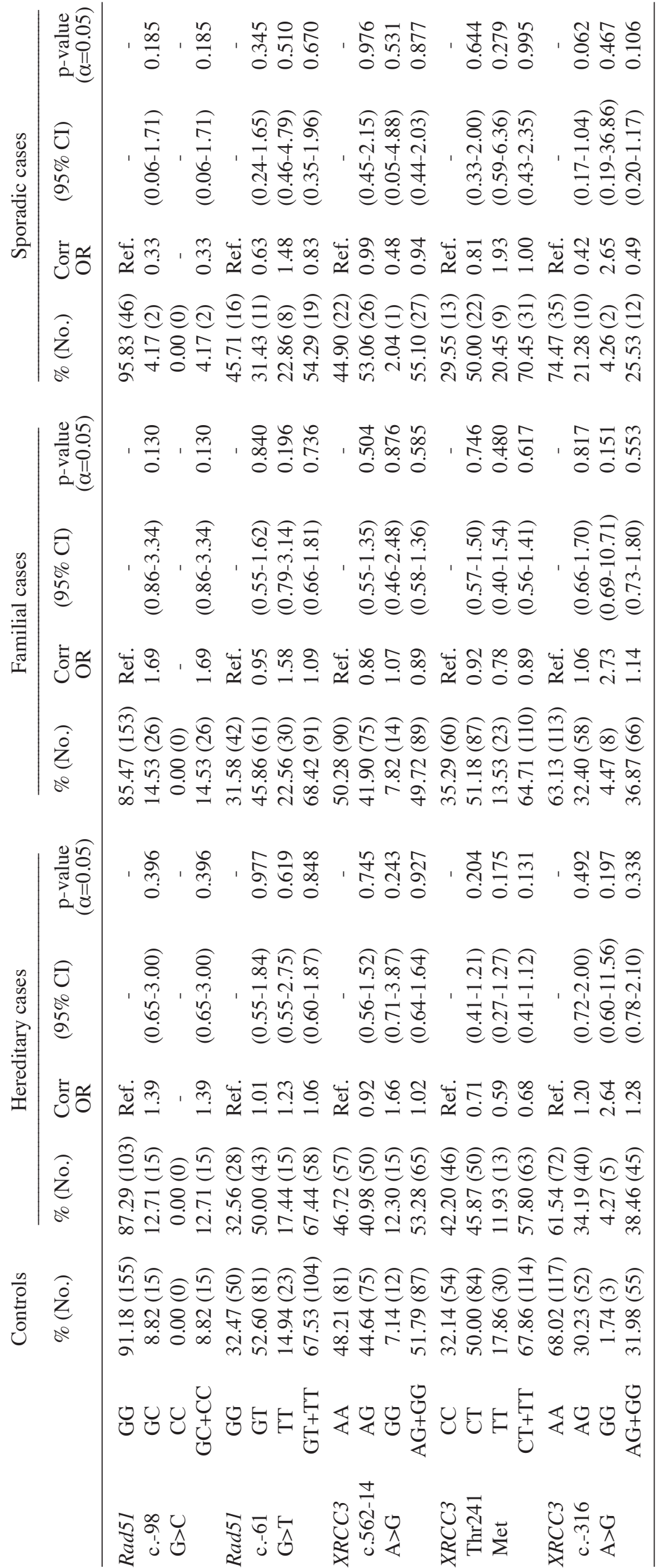

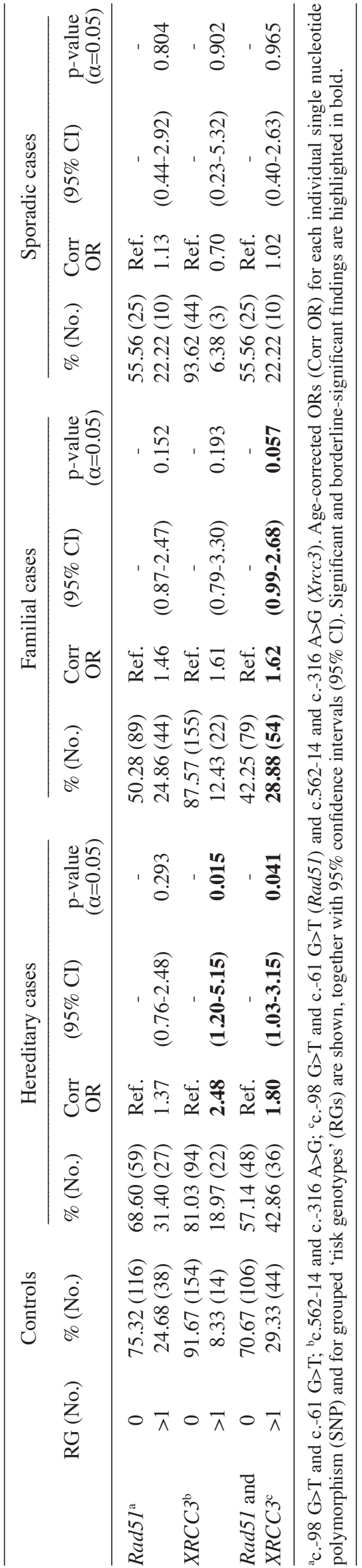




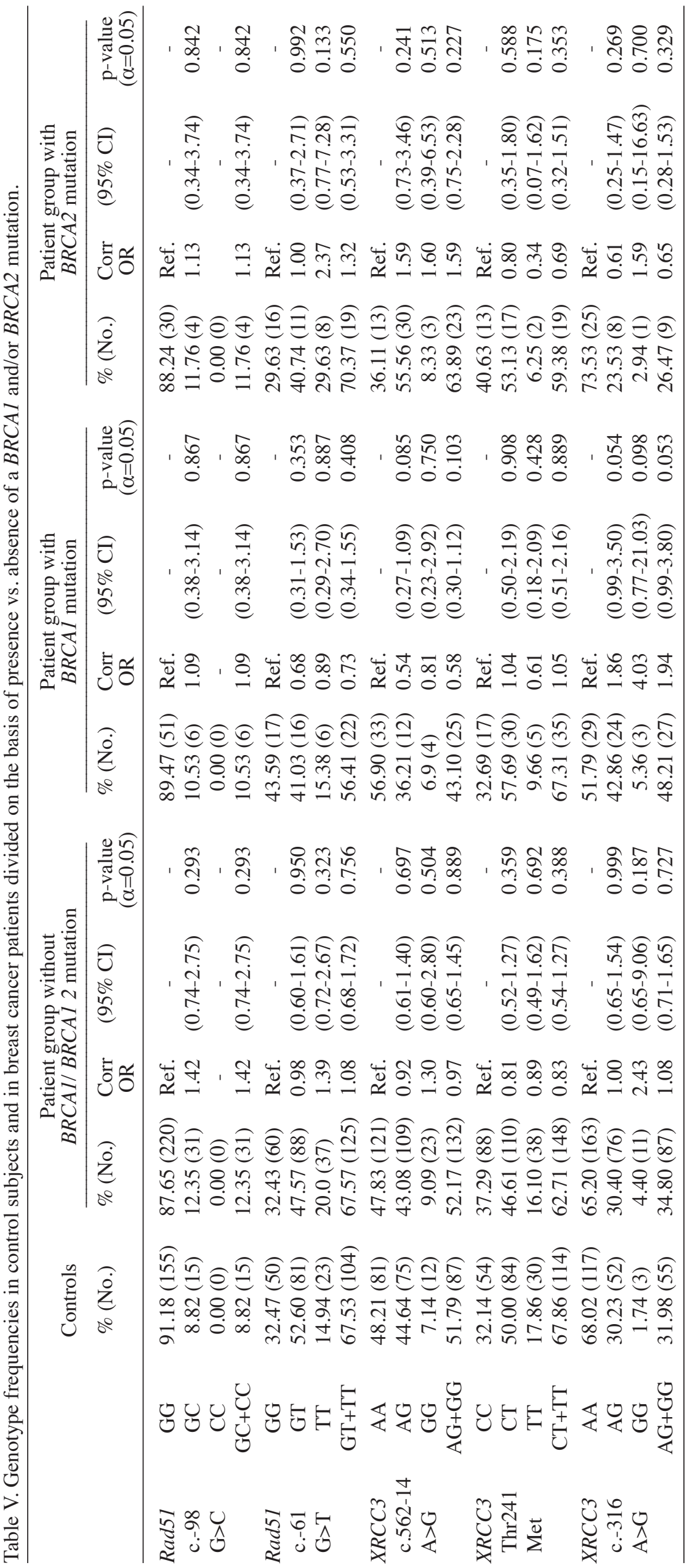

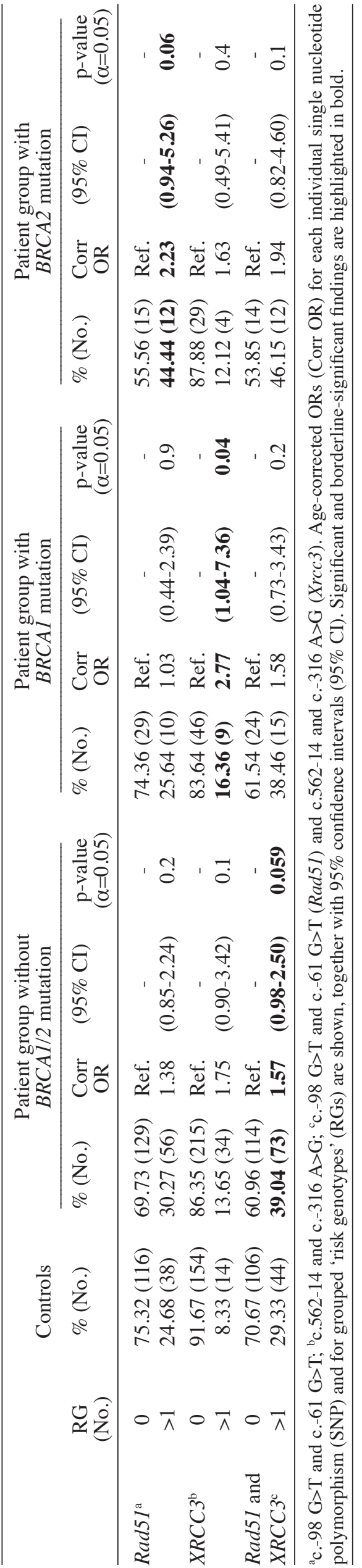




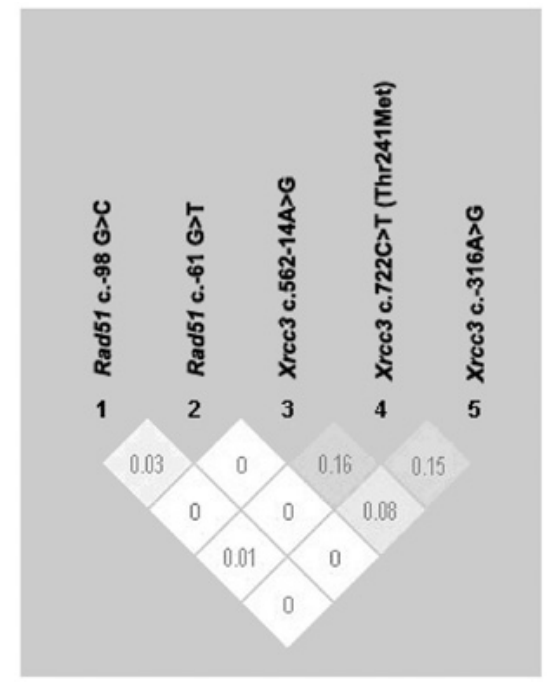

Figure 1. Linkage disequilibrium (LD) plot of the c.-98 G>C (rs1801320) and c.-61 G>T (rs1801321) variations in the 5' UTR of Rad51, and the c.562-14 $\mathrm{A}>\mathrm{G}$ (rs1799796), c.722 C>T (rs861539) and c.-316 A>G (rs1799794) variations in $X r c c 3$. Analysis was performed in 172 healthy control individuals. The LD coefficient $r^{2}$ is shown in the plot squares.

Since the five SNPs investigated in this study are not in LD with each other (Fig. 1), we analyzed whether the combination of different DSB repair risk genotypes (RGs) may result in a significant association with $\mathrm{BC}$ risk. For this specific analysis, the He genotype 'GC' of the c.-98 G>C SNP in Rad51 and the HV genotypes 'TT' of the c.-61 G>T variant $(\operatorname{Rad} 51)$, as well as 'GG' of c.562-14 A>G (Xrcc3) and 'GG' of c.-316 A>G $(X r c c 3)$, were considered as putative breast cancer susceptibility genotypes (Table III).

The ORs calculated for various combinations of DSB repair RGs and BC are shown in Tables III-V.

Combination of $\mathrm{Xrcc} 3 \mathrm{RG}$ resulted in high and significant ORs in the hereditary patient group $\left(\mathrm{OR}_{>\mathrm{RG}}=2.48 ; 95 \% \mathrm{CI}\right.$, 1.20-5.15; $\mathrm{p}=0.015$; Table IV) and $B R C A 1$ mutation carriers $\left(\mathrm{OR}_{>\mathrm{RG}}=2.77 ; 95 \%\right.$ CI: 1.04-7.36; $\mathrm{p}=0.041$; Table V $)$.

The combined Rad51 risk genotype analysis yielded ORs of $>1$ in most cases, indicating a possible enhancement of BC risk in the presence of at least 1 risk genotype. In particular, BRCA2 mutation carriers showed a borderline-significant $\mathrm{OR}_{>1 \mathrm{RG}}$ of 2.23 (95\% CI, 0.94-5.26; $\mathrm{p}=0.06$; Table V).

When all of the DSB repair genotypes were combined, a significant positive association between the putative risk alleles listed in the previous paragraph and $\mathrm{BC}$ was found in the total patient population $\left(\mathrm{OR}_{>1 \mathrm{RG}}=1.59 ; 95 \%\right.$, CI: 1.02-2.47; $\mathrm{p}=0.041$; Table III) and in hereditary cases (OR=1.80; 95\% CI, 1.03-3.15; $\mathrm{p}=0.04$, Table IV). Familial non-BRCA1 or non-BRCA2 cases showed borderline-significant ORs (Table V).

Variations in Rad51 and Xrcc3 and in vitro CRS. To examine the potential effect of the 5 variations under study on CRS, we previously determined the in vitro CRS of 62 patients and 100 healthy female individuals using the $\mathrm{G}_{2}$ chromatid-break or $\mathrm{G}_{0} \mathrm{MN}$ assays (4). In this study, the 75 percentiles of the $\mathrm{G}_{0}$ $\mathrm{MN}$ or $\mathrm{G}_{2}$ chromatid-break values calculated in the healthy female population were used as cut-off points for radiosensitivity, as previously described (8). Age-corrected ORs were calculated by logistic regression. The genotype frequencies in radiosensitive patients were compared to frequencies assessed in the non-radiosensitive patient group (Table VI). The two SNPs in Rad51 and the c.-316 A>G variation in $X r c c 3$ showed ORs of $<1$, suggesting a potential protective effect of the variant alleles towards CRS. High but nonsignificant ORs were assessed for the c.562-14 A $>$ G SNP in $X r c c 3(\mathrm{ORHe}=3.45$, ORHV=1.65) and for the He genotype of the c.722 C>T variation in $X r c c 3$ (ORHE=1.73).

A risk allele (RA) analysis was performed to assess the effect of combining different DSB repair variant alleles on CRS (Table VI). ORs of $<1$ were obtained by combining variant alleles of the SNPs in Rad51. The protective effect for radiosensitive patients carrying two Rad51 variant alleles was significant (OR2VA=0.10, 95\% CI, 0.01-0.96; $\mathrm{p}=0.046$; Table VI). Non-significant results were obtained by analyzing the combined effect of the c.562-14 A $>\mathrm{G}$ and c.722 $\mathrm{C}>\mathrm{T}$ SNPs in $X r c c 3$.

\section{Discussion}

Misrepair or inefficient repair of DSBs may lead to genetic instability and ultimately to carcinogenesis. This process is confirmed by the fact that different cancer-prone genetic disorders such as Ataxia-telangiectasia and Nijmegen Breakage syndrome, are linked to the HR-DSB repair pathway, and by the finding that genes involved in $\mathrm{HR}$, such as $B R C A l$ and $B R C A 2$, are tumor-suppressor genes (11). However, BC-predisposing genes such as BRCAl and BRCA2 account for only $15-20 \%$ of inherited susceptibility $(48,49)$. Epidemiological analysis suggests that the remaining $80-85 \%$ can mainly be explained by a polygenic model whereby the combined effects of numerous individual weak genetic variants are responsible for an enhanced breast cancer risk (50). This model is also supported by the results obtained in this study, where a significant association between the genetic variants and $\mathrm{BC}$ risk was observed only after combined risk genotype analysis.

Although the c.-98 G>C SNP in Rad51 was initially shown to have no impact on $\mathrm{BC}$ risk in the general $\mathrm{BC}$ population $(24,31,33,51)$, contradicting results were obtained concerning the effect of the variant ' $\mathrm{C}$ ' allele of c. $-98 \mathrm{G}>\mathrm{C}$ on $\mathrm{BC}$ risk in a population of $\mathrm{BC}$ patients with a familial history of the disease $(25,26,28)$. Various studies reported that the c.-98 G>C variation appeared to modify $\mathrm{BC}$ risk in $B R C A 1$ or $B R C A 2$ carriers. In their study, Jakubowska et al (27) demonstrated a protective effect of this variation on $\mathrm{BC}$ susceptibility in cases carrying the BRCAl gene, one of the three most common Polish founder mutations. Notably, a protective effect was also shown against colon cancer risk in Polish cohorts (52).

In different studies involving $B R C A 2$ mutation carriers, the c.-98 $\mathrm{G}>\mathrm{C}$ variation was shown to enhance $\mathrm{BC}$ susceptibility $(29,30,32)$. In 2007 , a meta-analysis of 19 studies confirmed that the c. $-98 \mathrm{G}>\mathrm{C}$ SNP is a BC risk modifier in $B R C A 2$, but not in BRCA1 mutation carriers (23). A significant odds ratio was also found between $\mathrm{BC}$ risk and c. $-98 \mathrm{G}>\mathrm{C}$ in BRCA2 mutation carriers in a recent meta-analysis by Zhou and coworkers (53). Most recently, four meta-analysis studies were published concerning the role of the c.-98 G>C SNP in breast cancer predisposition (53-56). With the exception of the Yu et al study (55), the findings of the meta-analyses showed a 
Table VI. Genotype frequencies, age-corrected OR and 95\% confidence intervals (95\% CI) assessed in both radiosensitive (RS) and non-radiosensitive (NRS) cases.

\begin{tabular}{|c|c|c|c|c|c|c|}
\hline & & \multirow{2}{*}{$\begin{array}{l}\text { NRS cases } \\
\% \text { (No.) }\end{array}$} & \multicolumn{4}{|c|}{ RS cases } \\
\hline & & & $\%$ (No.) & Corr OR & $(95 \% \mathrm{CI})$ & $\mathrm{p}(\alpha=0.05)$ \\
\hline \multirow{4}{*}{$\begin{array}{c}\text { Rad } 51 \\
\text { c. }-98 \\
\mathrm{G}>\mathrm{C}\end{array}$} & GG & $78.57(22)$ & $88.24(15)$ & - & - & - \\
\hline & $\mathrm{GC}$ & $21.43(6)$ & $11.76(2)$ & 0.49 & $(0.09-2.78)$ & 0.422 \\
\hline & $\mathrm{CC}$ & $0.00(0)$ & $0.00(0)$ & - & - & - \\
\hline & $\mathrm{GC}+\mathrm{CC}$ & $21.43(6)$ & $11.76(2)$ & 0.49 & $(0.09-2.78)$ & 0.422 \\
\hline \multirow{4}{*}{$\begin{array}{c}\operatorname{Rad} 51 \\
\text { c. }-61 \\
\mathrm{G}>\mathrm{T}\end{array}$} & GG & 16.67 (4) & $33.33(5)$ & - & - & - \\
\hline & GT & $45.83(11)$ & $46.67(7)$ & 0.50 & $(0.10-2.54)$ & 0.402 \\
\hline & $\mathrm{TT}$ & $37.50(9)$ & $20.00(3)$ & 0.27 & $(0.04-1.70)$ & 0.161 \\
\hline & $\mathrm{GT}+\mathrm{TT}$ & $83.33(20)$ & $66.67(10)$ & 0.39 & $(0.09-1.81)$ & 0.230 \\
\hline \multirow{4}{*}{$\begin{array}{l}X R C C 3 \\
\text { c. } 562-14 \\
A>G\end{array}$} & $\mathrm{AA}$ & $67.86(19)$ & $47.06(8)$ & - & - & - \\
\hline & $\mathrm{AG}$ & $21.43(6)$ & $41.18(7)$ & 3.45 & $(0.78-15.31)$ & 0.104 \\
\hline & GG & $10.71(3)$ & $11.76(2)$ & 1.65 & $(0.23-12.06)$ & 0.622 \\
\hline & $\mathrm{AG}+\mathrm{GG}$ & $32.14(9)$ & $52.94(9)$ & 2.73 & $(0.73-10.17)$ & 0.135 \\
\hline \multirow{4}{*}{$\begin{array}{l}\text { XRCC3 } \\
\text { Thr241 } \\
\text { Met }\end{array}$} & $\mathrm{CC}$ & $37.04(10)$ & $35.29(6)$ & - & - & - \\
\hline & $\mathrm{CT}$ & 40.74 (11) & $58.82(10)$ & 1.73 & $(0.44-6.83)$ & 0.437 \\
\hline & $\mathrm{TT}$ & $22.22(6)$ & $5.88(1)$ & 0.26 & $(0.02-2.76)$ & 0.262 \\
\hline & $\mathrm{CT}+\mathrm{TT}$ & $62.96(17)$ & $64.71(11)$ & 1.12 & $(0.31-4.02$ & 0.863 \\
\hline \multirow{4}{*}{$\begin{array}{c}X R C C 3 \\
\mathrm{c} .-316 \\
\mathrm{~A}>\mathrm{G}\end{array}$} & $\mathrm{AA}$ & $65.38(17)$ & 76.47 (13) & - & - & - \\
\hline & $\mathrm{AG}$ & $34.62(9)$ & $23.53(4)$ & 0.58 & $(0.15-2.31)$ & 0.438 \\
\hline & GG & $0.00(0)$ & $0.00(0)$ & - & - & - \\
\hline & $\mathrm{AG}+\mathrm{GG}$ & $34.62(9)$ & $23.53(4)$ & 0.58 & $(0.15-2.31)$ & 0.438 \\
\hline
\end{tabular}

Risk allele analysis.

\begin{tabular}{|c|c|c|c|c|c|c|}
\hline & \multirow{2}{*}{$\begin{array}{l}\text { Risk alleles } \\
\text { (No.) }\end{array}$} & \multirow{2}{*}{$\begin{array}{l}\text { NRS cases } \\
\qquad \%(\mathrm{No})\end{array}$} & \multicolumn{4}{|c|}{ RS cases } \\
\hline & & & $\%(\mathrm{No})$ & Corr OR & $(95 \%$ CI $)$ & $\mathrm{p}(\alpha=0.05)$ \\
\hline \multirow[t]{4}{*}{$\operatorname{Rad} 51^{\mathrm{a}}$} & 0 & $8.70(2)$ & $28.57(4)$ & - & - & - \\
\hline & 1 & $47.83(11)$ & $57.14(8)$ & 0.37 & $(0.05-2.55)$ & 0.313 \\
\hline & 2 & $43.48(10)$ & $14.29(2)$ & 0.10 & $(0.01-0.96)$ & 0.046 \\
\hline & 3 & $4.35(1)$ & $7.14(1)$ & 0.56 & $(0.02-15.01)$ & 0.732 \\
\hline \multirow[t]{3}{*}{$X R C C 3^{\mathrm{b}}$} & 0 & $19.23(5)$ & $17.65(3)$ & - & - & - \\
\hline & 1 & $26.92(7)$ & $41.18(7)$ & 1.72 & $(0.29-10.23)$ & 0.551 \\
\hline & 2 & $53.85(14)$ & $41.18(7)$ & 0.89 & $(0.16-4.94)$ & 0.889 \\
\hline
\end{tabular}

${ }^{\mathrm{a}} \mathrm{c} .-98 \mathrm{G}>\mathrm{T}$ and c.-61 G>T; ${ }^{\mathrm{b}} \mathrm{c} .562-14$ and Thr241Met. The odds ratios (ORs) for each individual single nucleotide polymorphism (SNP) and for the risk allele analysis are shown. Significant findings are highlighted in bold.

significant association with BC risk in the carriers of the c.-98 $\mathrm{G}>\mathrm{C}$ variation. In particular, the study by Gao et al demonstrated a correlation between the CC genotype and elevated $\mathrm{BC}$ risk in sporadic patients and in the broader European population (54). Although no significant association of this polymorphism with $\mathrm{BC}$ was found by Wang et al in overall and European populations, the authors observed a significant increase in breast cancer risk (recessive model $\mathrm{CC}$ vs. GG/ CG: $\mathrm{OR}=1.35,95 \% \mathrm{CI}, 1.05-1.74)$ following the exclusion of studies that did not show a Hardy-Weinberg equilibrium for the SNP (56). Finally, the Zhou study found significant ORs in both additive $(1.34 ; 95 \% \mathrm{CI}, 1.01-1.78)$ and recessive $(1.37$; 95\% CI, 1.03-1.82) models (53).
The c.-61 G>T SNP in the 5' UTR of Rad51 has been studied less extensively and no association with BC risk was found $(32,57,58)$. Our results indicate that the He genotype of c.-98 G>C and the HV genotype of c.-61 G>T may be considered as putative RGs for $\mathrm{BC}$ since the combined effect of the two genotypes exhibited a borderline significant OR of 2.23 in the BC patient group with a BRCA2 mutation (95\% CI, 0.945.26). This combined effect on $\mathrm{BC}$ risk in $B R C A 2$ carriers may be due to the fact that the c. $-98 \mathrm{G}>\mathrm{C}$ and c.- $61 \mathrm{G}>\mathrm{T}$ variations are functional and result in an increased promoter activity (59).

The functionality of the two variations also substantiates the finding that the variant alleles of the two SNPs in Rad51 have a protective effect towards in vitro CRS. The protective 
effect became significant after analysis of the combined risk alleles $\left(\mathrm{OR}_{2 \mathrm{RA}}=0.10,95 \% \mathrm{CI}, 0.01-0.96\right.$; $\mathrm{p}=0.046$; Table VI). According to Hasselbach et al (59), the two variations are gain-of-function mutations. This observation explains the protection observed towards in vitro CRS as cells with an increased level of Rad51 are expected to be more resistant to DNA damage. The enhanced BC risk observed in BRCA2 mutation carriers in this study appear to be contradictory to this rationale. However, increased levels of Rad51 have been found in cell lines derived from breast carcinoma. It is likely that a balanced relationship between Rad51 expression and other repair factors is required. Additionally, the overexpression of Rad51 may lead to increased genomic instability and therefore contribute to carcinogenesis (60). In contrast to Hasselbach et al (59), Antoniou et al (23) found that the c.-98 'C' allele may cause an overall lower abundance of the Rad51 protein. The effects of these SNPs on Rad51 protein levels, particularly in breast tissue, require further investigation.

The association between the c.562-14 A>G SNP in Xrcc3 and $\mathrm{BC}$ is controversial. Some studies showed a protective effect of the HV genotype against BC $(58,36)$, whereas other reports showed no association with $\mathrm{BC}$ risk (37).

Kuschel et al (58) revealed that the c.-316 A>G variation in $X r c c 3$ did not correlate with BC susceptibility. The Breast Cancer Consortium pooled data from 5 and 6 studies focusing on c.562-14 $\mathrm{A}>\mathrm{G}$ and c.-316 $\mathrm{A}>\mathrm{G}$, respectively, and found no correlation between the frequency of the variant alleles and $\mathrm{BC}$ risk (34). In our study, positive but non-significant ORs were obtained for the rare HV genotype of the two SNPs. However, the analysis performed by combining the two HV RGs, resulted in significant ORs in hereditary $\left(\mathrm{OR}_{>1 \mathrm{RG}}=2.48 ; 95 \%\right.$ CI, 1.20-5.15; $\mathrm{p}=0.015$; Table IV) and in BRCA1 patient groups $\left(\mathrm{OR}_{>1 \mathrm{RG}}=2.77\right.$; 95\% CI, 1.04-7.36; $\mathrm{p}=0.041$; Table V $)$, and borderline-significant-positive ORs for the total patient population $\left(\mathrm{OR}_{>1 \mathrm{RG}}=1.79 ; 95 \% \mathrm{CI}, 0.94-3.41 ; \mathrm{p}=0.076\right.$; Table III $)$. Houlston and Peto (61) estimated that, depending on the risk exhibited by a variant allele, genotype studies in familial populations may be 2-5 times more powerful than studies involving unselected patients. The genotyping explains the occurence of the strongest associations between SNPs and $\mathrm{BC}$ in the hereditary patient group. The strong association observed in BRCA1 patients indicates that low-penetrant variations are capable of modifying $\mathrm{BC}$ risk in patients already carrying a high penetrant mutation. Although the BRCA1 and Xrcc3 proteins do not physically interact, both are indispensable components of the same HR pathway. Xrcc3 is essential for the Rad51 filament formation (20), whereas BRCA1 plays a role as a 'molecular scaffold' for the assembly of the HR machinery, and recruits checkpoint factors to initiate a signalling cascade that halts cell cycle progression (10).

The c.722 C>T variation in Xrcc3, encoding the missense mutation Thr241Met, has been extensively studied. Published data have produced varying results, ranging from i) a protective effect towards BC (37), particularly in post-menopausal women carrying at least one ' $\mathrm{T}$ ' allele (57); to ii) no association with breast (or colon) cancer risk $(26,33,38,42,62)$; to iii) an enhanced susceptibility to BC, $(58,25,35-37,39-41,43)$; or iv) to an increased risk of onset of local metastases (51). A pooled analysis of nine studies revealed no association of the variant ' $\mathrm{T}$ ' allele with breast cancer (34). Our results confirm the absence of an association between the presence of the variant ' $\mathrm{T}$ ' allele and BC risk (Tables III-V). The lack of an association between this variation and BC is further supported by the fact that no significant difference in DNA repair activity was found between cells expressing the wild-type Thr protein of $X r c c 3$ and the Met variant (63).

$X r c c 3$ has also been extensively tested for its association with in vivo radiosensitivity after radiotherapy in a variety of cancers (reviewed in ref. 64). The majority of the studies studies failed to note a correlation between the c.722 C>T variant and radiotherapy-induced acute complications (64). However, in non-cancer subjects the protein encoded by the gene harboring the $\mathrm{c} .722 \mathrm{C}>\mathrm{T}$ variant has been found to repair radiation-induced damage with significantly less efficiency than its wild-type counterpart (65). In patients treated for gynaecological tumors, the c.-316 A > G SNP exhibited an association with incidence of cancer, but not with the development of acute reactions following radiotherapy. In the same study, the c.562-14 $\mathrm{A}>\mathrm{G}$ variation exhibited no correlation with cancer incidence, but the variant ' $G$ ' allele was predisposed to more severe acute complications following radiotherapy (66). When genotype distributions were compared in radiosensitive vs. non-radiosensitive $\mathrm{BC}$ patients (Table VI), the positive ORs exhibited by c.562-14 A $>\mathrm{G}$ and c.722 $\mathrm{C}>\mathrm{T}$ may indicate that these SNPs are correlated with in vitro CRS. However, risk allele analysis results were inconclusive.

In conclusion, the effects of SNPs in Rad51 and Xrcc3 on $\mathrm{BC}$ risk remain to be elucidated. Nevertheless, findings of this study revealed that low-penetrant variations in Rad51 and $X r c c 3$, two proteins belonging to the HR repair pathway, may modify $\mathrm{BC}$ risk in patients already carrying a pathological mutation in the highly penetrant $\mathrm{BC}$ genes $B R C A l$ and $B R C A 2$. Combined risk genotype analysis also revealed that Rad51 SNPs enhanced BC risk in BRCA2 patients, whereas Xrcc3 SNPs enhanced BC risk in BRCAl patients and in patients with hereditary $B C$. When the four putative RGs of Rad51 and Xrcc3 were combined, a positive significant OR was observed for the total patient population. This finding is supportive of a polygenic model whereby combinations of weak variations are responsible for enhanced breast cancer risk. Since the different subpopulations of BC patients used in this report were relatively small, larger sample sizes are required to confirm the conclusions (study in progress).

\section{Acknowledgements}

We wish to thank all patients and volunteers who participated in this study. The study was partly supported by a grant of the 'Bijzonder Onderzoeksfonds' (Ghent University, No B/05780/01), by a 'VLIR Own Initiative Programme' (ZEIN2005PR309) and by a grant of the Research Foundation Flanders (FWO, No 1.5.080.08). International mobility for this collaborative project, including work cited in references 15, 16, 17 and 18, were partly funded by the INTERLINK project of the Italian Ministry of University/Education.

\section{References}

1. Parkin DM, Bray F, Ferlay J and Pisani : Global cancer statistics, 2002. CA Cancer J Clin 55: 74-108, 2005. 
2. Ferlay J, Autier P, Boniol M, Heanue M, Colombet M and Boyle P: Estimates of the cancer incidence and mortality in Europe in 2006. Ann Oncol 18: 581-592, 2007.

3. Baeyens A, Thierens H, Claes K, Poppe B, Messiaen L, de Ridder L and Vral A: Chromosomal radiosensitivity in breast cancer patients with a known or putative genetic predisposition. Br J Cancer 87: 1379-1385, 2002.

4. Baeyens A, van den Broecke $R$, Makar A, Thierens $H$, de Ridder L and Vral A: Chromosomal radiosensitivity in breast cancer patients: Influence of age of onset of the disease. Oncol Rep 13: 347-353, 2005.

5. Jones LA, Scott D, Cowan R and Roberts SA: Abnormal radiosensitivity of lymphocytes from breast cancer patients with excessive normal tissue damage after radiotherapy: chromosome aberrations after low dose-rate irradiation. Int J Radiat Biol 67: 519-528, 1995

6. Scott D, Barber JB, Levine EL, Burrill W and Roberts SA: Radiation-induced micronucleus induction in lymphocytes identifies a high frequency of radiosensitive cases among breast cancer patients: a test for predisposition? Br J Cancer 77: 614-20, 1998.

7. Scott D, Barber JB, Spreadborough AR, Burrill W and Roberts SA: Increased chromosomal radiosensitivity in breast cancer patients: a comparison of two assays. Int J Radiat Biol 75: $1-10,1999$.

8. Varga D, Hoegel J, Maier C, Jainta S, Hoehne M, PatinoGarcia B, Michel I, Schwarz-Boeger U, Kiechle M, Kreienberg R and Vogel W: On the difference of micronucleus frequencies in peripheral blood lymphocytes between breast cancer patients and controls. Mutagenesis 21: 313-320, 2006.

9. Varga D, Vogel W, Bender A, Surowy H, Maier C, Kreienberg R, Deissler $\mathrm{H}$ and Sauer G: Increased radiosensitivity as an indicator of genes conferring breast cancer susceptibility. Strahlenther Onkol 183: 655-660, 2007.

10. Ralhan R, Kaur J, Kreienberg R and Wiesmüller L: Links between DNA double strand break repair and breast cancer: accumulating evidence from both familial and nonfamilial cases. Cancer Lett 248: 1-17, 2007.

11. Thompson LH and Schild D: Recombinational DNA repair and human disease. Mutat Res 509: 49-78, 2002.

12. Valerie $\mathrm{K}$ and Povirk LF: Regulation and mechanisms of mammalian double-strand break repair. Oncogene 22: 5792-5812, 2003.

13. Ferguson DO and Alt FW: DNA double strand break repair and chromosomal translocation: lessons from animal models. Oncogene 20: 5572-5579, 2001.

14. Gatti RA: The inherited basis of human radiosensitivity. Acta Oncol 40: 702-711,2001.

15. Vandersickel V, Depuydt J, van Bockstaele B, Perletti G, Philippe J, Thierens $\mathrm{H}$ and Vral A: Early increase of radiationinduced $\gamma \mathrm{H} 2 \mathrm{AX}$ foci in a human Ku70/80 knockdown cell line characterized by an enhanced radiosensitivity. J Radiat Res (Tokyo) 51: 633-641, 2010.

16. Vandersickel V, Mancini M, Slabbert J, Marras E, Thierens H, Perletti G and Vral A: The radiosensitizing effect of Ku70/80 knockdown in MCF10A cells irradiated with X-rays and $\mathrm{p}(66)+\mathrm{Be}(40)$ neutrons. Radiat Oncol 5: 30, 2010.

17. Willems P, de Ruyck K, van den Broecke R, Makar A, Perletti G, Thierens $\mathrm{H}$ and Vral A: A polymorphism in the promoter region of Ku70/XRCC6, associated with breast cancer risk and oestrogen exposure. J Cancer Res Clin Oncol 135: 1159-1168, 2009.

18. Willems P, Claes K, Baeyens A, Vandersickel V, Werbrouck J, de Ruyck K, Poppe B, van den Broecke R, Makar A, Marras E, Perletti G, Thierens H and Vral A: Polymorphisms in nonhomologous end-joining genes associated with breast cancer risk and chromosomal radiosensitivity. Genes Chromosomes Cancer 47: 137-148, 2008. Erratum in: Genes Chromosomes Cancer 48 $381,2009$.

19. Dudás A and Chovanec M: DNA double-strand break repair by homologous recombination. Mutat Res 566: 131-167, 2004.

20. Li $X$ and Heyer WD: Homologous recombination in DNA repair and DNA damage tolerance. Cell Res 18: 99-113, 2008.

21. Liu Y, Masson JY, Shah R, O'Regan P and West SC: RAD51C is required for Holliday junction processing in mammalian cells. Science 303: 243-246, 2004

22. Bishop DK, Ear U, Bhattacharyya A, Calderone C, Beckett M, Weichselbaum RR and Shinohara A: Xrcc3 is required for assembly of Rad51 complexes in vivo. J Biol Chem 273: 21482-21488, 1998.
23. Antoniou AC, Sinilnikova OM, Simard J, et al: Consortium of Investigators of Modifiers of BRCA1/2 (CIMBA). RAD51 135G- C modifies breast cancer risk among BRCA2 mutation carriers: results from a combined analysis of 19 studies. Am J Hum Genet 81: 1186-1200, 2007.

24. Blasiak J, Przybyłowska K, Czechowska A, Zadrozny M, Pertyński T, Rykała J, Kołacińska A, Morawiec Z and Drzewoski J: Analysis of the $\mathrm{G} / \mathrm{C}$ polymorphism in the 5'-untranslated region of the RAD51 gene in breast cancer. Acta Biochim Pol 50: 249-253, 2003.

25. Costa S, Pinto D, Pereira D, Rodrigues H, Cameselle-Teijeiro J, Medeiros R and Schmitt F: DNA repair polymorphisms might contribute differentially on familial and sporadic breast cancer susceptibility: a study on a Portuguese population. Breast Cancer Res Treat 103: 209-217, 2007.

26. Dufloth RM, Costa S, Schmitt F and Zeferino LC: DNA repair gene polymorphisms and susceptibility to familial breast cancer in a group of patients from Campinas, Brazil. Genet Mol Res 4: 771-782. 2005

27. Jakubowska A, Gronwald J, Menkiszak J, Górski B, Huzarski T, Byrski T, Edler L, Lubiñski J, Scott RJ and Hamann U: The RAD51 $135 \mathrm{G}>\mathrm{C}$ polymorphism modifies breast cancer and ovarian cancer risk in Polish BRCA1 mutation carriers. Cancer Epidemiol Biomarkers Prev 16: 270-275, 2007.

28. Jara L, Acevedo ML, Blanco R, Castro VG, Bravo T, Gómez F, Waugh E, Peralta O, Cabrera E, Reyes JM, Ampuero S and González-Hormazábal P: RAD51 135G $>$ C polymorphism and risk of familial breast cancer in a South American population. Cancer Genet Cytogenet 178: 65-69, 2007.

29. Kadouri L, Kote-Jarai Z, Hubert A, Durocher F, Abeliovich D, Glaser B, Hamburger T, Eeles RA and Peretz T: A singlenucleotide polymorphism in the RAD51 gene modifies breast cancer risk in BRCA2 carriers, but not in BRCA1 carriers or noncarriers. Br J Cancer 90: 2002-2005, 2004.

30. Levy-Lahad E, Lahad A, Eisenberg S, Dagan E, Paperna T, Kasinetz L, Catane R, Kaufman B, Beller U, Renbaum P and Gershoni-Baruch R: A single nucleotide polymorphism in the RAD51 gene modifies cancer risk in BRCA2 but not BRCA1 carriers. Proc Natl Acad Sci USA 98: 3232-3236, 2001.

31. Sliwinski T, Krupa R, Majsterek I, Rykala J, Kolacinska A, Morawiec Z, Drzewoski J, Zadrozny $M$ and Blasiak J: Polymorphisms of the BRCA2 and RAD51 genes in breast cancer. Breast Cancer Res Treat 94: 105-109, 2005.

32. Wang WW, Spurdle AB, Kolachana P, Bove B, Modan B, Ebbers SM, Suthers G, Tucker MA, Kaufman DJ, Doody MM, Tarone RE, Daly M, Levavi H, Pierce H, Chetrit A, Yechezkel GH, Chenevix-Trench G, Offit K, Godwin AK and Struewing JP: A single nucleotide polymorphism in the 5 ' untranslated region of RAD51 and risk of cancer among BRCA1/2 mutation carriers. Cancer Epidemiol Biomarkers Prev 10: 955-960, 2001

33. Webb PM, Hopper JL, Newman B, Chen X, Kelemen L, Giles GG, Southey MC, Chenevix-Trench G and Spurdle AB: Double-strand break repair gene polymorphisms and risk of breast or ovarian cancer. Cancer Epidemiol Biomarkers Prev 14: 319-323, 2005.

34. Breast Cancer Association Consortium: Commonly studied single-nucleotide polymorphisms and breast cancer: results from the Breast Cancer Association Consortium. J Natl Cancer Inst 98:1382-1396, 2006. Erratum in: J Natl Cancer Inst 99: 411, 2007.

35. Figueiredo JC, Knight JA, Briollais L, Andrulis IL and Ozcelik H: Polymorphisms XRCC1-R399Q and XRCC3-T241M and the risk of breast cancer at the Ontario site of the Breast Cancer Family Registry. Cancer Epidemiol Biomarkers Prev 13: 583-591, 2004

36. García-Closas M, Egan KM, Newcomb PA, Brinton LA, TitusErnstoff L, Chanock S, Welch R, Lissowska J, Peplonska B, Szeszenia-Dabrowska N, Zatonski W, Bardin-Mikolajczak A and Struewing JP: Polymorphisms in DNA double-strand break repair genes and risk of breast cancer: two population-based studies in USA and Poland, and meta-analyses. Hum Genet 119: 376-388, 2006

37. Han J, Hankinson SE, Ranu H, de Vivo I and Hunter DJ: Polymorphisms in DNA double-strand break repair genes and breast cancer risk in the Nurses' Health Study. Carcinogenesis 25: 189-195, 2004.

38. Millikan RC, Player JS, Decotret AR, Tse CK and Keku T: Polymorphisms in DNA repair genes, medical exposure to ionizing radiation, and breast cancer risk. Cancer Epidemiol Biomarkers Prev 14: 2326-2334, 2005. 
39. Sangrajrang S, Schmezer P, Burkholder I, Boffetta P, Brennan P, Woelfelschneider A, Bartsch $\mathrm{H}$, Wiangnon S, Cheisilpa A and Popanda O: The XRCC3 Thr241Met polymorphism and breast cancer risk: a case-control study in a Thai population. Biomarkers 12: 523-532, 2007

40. Smith TR, Levine EA, Perrier ND, Miller MS, Freimanis RI, Lohman K, Case LD, Xu J, Mohrenweiser HW and Hu JJ: DNA-repair genetic polymorphisms and breast cancer risk. Cancer Epidemiol Biomarkers Prev 12: 1200-1204, 2003.

41. Smith TR, Miller MS, Lohman K, Lange EM, Case LD, Mohrenweiser $\mathrm{HW}$ and $\mathrm{Hu} \mathrm{JJ}$ : Polymorphisms of XRCC1 and XRCC3 genes and susceptibility to breast cancer. Cancer Lett 190: 183-190, 2003.

42. Thyagarajan B, Anderson KE, Folsom AR, Jacobs DR Jr, Lynch CF, Bargaje A, Khaliq W and Gross MD: No association between XRCC1 and XRCC3 gene polymorphisms and breast cancer risk: Iowa Women's Health Study. Cancer Detect Prev 30: 313-321, 2006.

43. Zhang L, Zhang Z and Yan W: Single nucleotide polymorphisms for DNA repair genes in breast cancer patients. Clin Chim Acta 359: 150-155, 2005.

44. Claes K, Poppe B, Coene I, Paepe AD and Messiaen L: BRCA1 and BRCA2 germline mutation spectrum and frequencies in Belgian breast/ovarian cancer families. $\mathrm{Br} \mathrm{J}$ Cancer 90: 1244-1251, 2004.

45. HGVS: http://www.hgvs.org/mutnomen

46. Barrett JC, Fry B, Maller J and Daly MJ: Haploview: analysis and visualization of $\mathrm{LD}$ and haplotype maps. Bioinformatics 21 : 263-265, 2005

47. NCBI: http://www.ncbi.nlm.nih.gov/

48. Hopper JL: Genetic epidemiology of female breast cancer. Semin Cancer Biol 11: 367-374, 2001.

49. Nathanson KL, Wooster R and Weber BL: Breast cancer genetics: what we know and what we need. Nat Med. 7: 552-556, 2001 Erratum in: Nat Med 7: 749, 2001.

50. Antoniou AC, Pharoah PD, McMullan G, Day NE, Stratton MR, Peto J, Ponder BJ and Easton DF: A comprehensive model for familial breast cancer incorporating BRCA1, BRCA2 and other genes. Br J Cancer 86: 76-83, 2002.

51. Krupa R, Synowiec E, Pawlowska E, Morawiec Z, Sobczuk A, Zadrozny M, Wozniak K and Blasiak J: Polymorphism of the homologous recombination repair genes RAD51 and XRCC3 in breast cancer. Exp Mol Pathol 87: 32-35, 2009.

52. Krupa R, Sliwinski T, Wisniewska-Jarosinska M, Chojnacki J, Wasylecka M, Dziki L, Morawiec J and Blasiak J: Polymorphisms in RAD51, XRCC2 and XRCC3 genes of the homologous recombination repair in colorectal cancer - a case control study. Mol Biol Rep Nov 20, 2010 (Epub ahead of print), DOI: $10.1007 / \mathrm{s} 11033-010-0430-6$

53. Zhou GW, Hu J, Peng XD and Li Q: RAD51 135G>C polymorphism and breast cancer risk: a meta-analysis. Breast Cancer Res Treat 125: 529-35, 2011.

54. Gao LB, Pan XM, Li LJ, Liang WB, Zhu Y, Zhang LS, Wei YG, Tang $M$ and Zhang L: RAD51 135G/C polymorphism and breast cancer risk: a meta-analysis from 21 studies. Breast Cancer Res Treat 125: 827-835, 2011 .
55. Yu KD, Yang C, Fan L, Chen AX and Shao ZM: RAD51 $135 \mathrm{G}>\mathrm{C}$ does not modify breast cancer risk in non-BRCA1/2 mutation carriers: evidence from a meta-analysis of 12 studies. Breast Cancer Res Treat May 12, 2010 (Epub ahead of print), DOI: 10.1007/s10549-010-0937-5.

56. Wang Z, Dong H, Fu Y and Ding H: RAD51 135G $>$ C polymorphism contributes to breast cancer susceptibility: a meta-analysis involving 26,444 subjects. Breast Cancer Res Treat 124: 765-769, 2010

57. Silva SN, Tomar M, Paulo C, Gomes BC, Azevedo AP Teixeira V, Pina JE, Rueff J and Gaspar JF: Breast cancer risk and common single nucleotide polymorphisms in homologous recombination DNA repair pathway genes XRCC2, XRCC3, NBS1 and RAD51. Cancer Epidemiol 34: 85-92, 2010.

58. Kuschel B, Auranen A, McBride S, Novik KL, Antoniou A, Lipscombe JM, Day NE, Easton DF, Ponder BA, Pharoah PD and Dunning A: Variants in DNA double-strand break repair genes and breast cancer susceptibility. Hum Mol Genet 11: 1399-1407, 2002.

59. Hasselbach L, Haase S, Fischer D, Kolberg HC and Stürzbecher HW: Characterisation of the promoter region of the human DNA-repair gene Rad51. Eur J Gynaecol Oncol 26: 589-598, 2005.

60. Klein HL: The consequences of Rad51 overexpression for normal and tumor cells. DNA Repair (Amst) 7: 686-693, 2008.

61. Houlston RS and Peto J: The future of association studies of common cancers. Hum Genet 112:434-435, 2003

62. Loizidou MA, Michael T, Neuhausen SL, Newbold RF, Marcou Y, Kakouri E, Daniel M, Papadopoulos P, Malas S, Kyriacou $\mathrm{K}$ and Hadjisavvas A: Genetic polymorphisms in the DNA repair genes XRCC1, XRCC2 and XRCC3 and risk of breast cancer in Cyprus. Breast Cancer Res Treat 112: 575-579, 2008.

63. Araujo FD, Pierce AJ, Stark JM and Jasin M: Variant XRCC3 implicated in cancer is functional in homology-directed repair of double-strand breaks. Oncogene 21: 4176-4180, 2002.

64. Chistiakov DA, Voronova NV and Chistiakov PA: Genetic variations in DNA repair genes, radiosensitivity to cancer and susceptibility to acute tissue reactions in radiotherapy-treated cancer patients. Acta Oncol 47: 809-824, 2008.

65. Au WW, Salama SA and Sierra-Torres CH: Functional characterization of polymorphisms in DNA repair genes using cytogenetic challenge assays. Environ Health Perspect 111: $1843-1850,2003$

66. De Ruyck K, van Eijkeren M, Claes K, Morthier R, de Paepe A, Vral A, de Ridder L and Thierens H: Radiation-induced damage to normal tissues after radiotherapy in patients treated for gynecologic tumors: association with single nucleotide polymorphisms in XRCC1, XRCC3, and OGG1 genes and in vitro chromosomal radiosensitivity in lymphocytes. Int $\mathrm{J}$ Radiat Oncol Biol Phys 62: 1140-1149, 2005. 